J. Perinat. Med. 15 (1987) 291

\title{
The prevalence of congenital abnormalities in patients with positive contraction stress tests
}

\author{
Hein J. Odendaal
}

Department of Obstetrics and Gynecology, Tygerberg Hospital and the University of Stellenbosch, Parow Valley, South Africa

\section{Introduction}

There is a significant increase in fetal heart rate abnormalities in fetuses with major congenital abnormalities. The neonatal death rate in these malformed infants may be as high as $44 \%$ [1]. When repeated late decelerations of the fetal heart rate is detected antenatally, delivery of the fetus is usually indicated and the most preferential method of delivering such a fetus is by cesarean section $[9,12]$. Severe preeclampsia is one of the main causes for positive concentration stress tests. As one would not choose to do a cesarean section in a very ill patient where there is a possibility of neonatal death due to major congenital abnormalities, it is important to know what the incidence of such abnormalities is in patients with positive contraction stress tests.

\section{Patients and methods}

Since the introduction of antenatal fetal heart rate monitoring at the Tygerberg Hospital in January 1975, all obstetrical and neonatal data of patients who were delivered because of repeated late decelerations were carefully kept for later reference. Newborns were prospectively followed up until discharge from the hospital. All neonatal complications were listed. At the beginning of the study, only stress tests were

\section{Curriculum vitae}

H. J. ODENDAAL obtained his M.B. Ch.B. from the University of Pretoria and specialized in Obstetrics and Gynecology at the University of Stellenbosch. He later obtained his M.D. from the same University and was appointed head of the Department of Obstetrics and Gynecology in 1983. In 1972 he was ad-

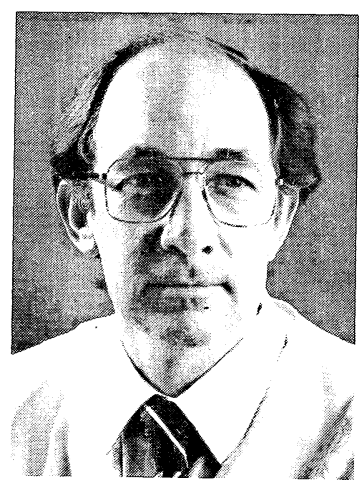
mitted as a member of the Royal College of Obstetricians and Gynecologists, and received his fellowship in 1982.

done, but when it became clear that acceleration patterns also reflect fetal wellbeing, nonstress tests were done and stress tests were only indicated when repeated nonreactive nonstress tests were encountered. Initially oxytocin was used to stimulate the uterus, but later nipple stimulation was introduced. Only tests which showed repeated late decelerations were regarded as positive. Extreme care was always taken not to interpret late decelerations caused by possible supine hypotension or overstimulation of the uterus as positive. Suspicious tests were routinely repeated before acted upon, unless the pregnancy was at term and the cervix favorable for induction of labor. If the cervix 
was unfavorable for the rupture of membranes and direct fetal monitoring or when the fetus was growth retarded delivery was done by cesarean section. The fetal heart rate was always monitored during labor. After delivery the fetus was examined by the pediatrician. In patients with intrauterine death, labor was usually induced and after delivery the fetus was examined for external abnormalities. Autopsies were not done on these babies.

\section{Results}

During the study period 60197 stress and nonstress tests were done in 25313 patients. There were $229(0.9 \%)$ positive tests. Preeclampsia and hypertension were the main indications $(47.2 \%)$ for the tests, followed by suspected intrauterine growth retardation $(26.6 \%)$ (table I). The mean age of the patients was 32 years. Nine percent of patients were 45 years or older, $7 \%$ between 40 and 44 years, $23 \%$ between 35 and 39 years, $30 \%$ between 30 and $34,20 \%$ between 25 and 29 years, $7 \%$ between 20 and 24 years and $4 \%$ younger than 20 years. Most of the patients $(70.7 \%)$ were delivered by cesarean section. Only $22.3 \%$ of patients delivered normally. Other methods of delivery were forceps $(3.9 \%)$, vacuum extraction $(2.2 \%)$ and breech delivery (0.9). There were 13 intrauterine deaths. In 9 of these the fetus was regarded as too small to be delivered and intrauterine death occurred soon after the repeated late decelerations had been noticed. The longest

Table I. Indications for antenatal fetal heart rate monitoring.

\begin{tabular}{lrr}
\hline Preeclampsia and hypertension & 108 & $(47.2 \%)$ \\
Suspected intrauterine growth & & \\
$\quad$ retardation & 61 & $(26.6 \%)$ \\
Postmaturity & 30 & $(13.1 \%)$ \\
Diabetes & 9 & $(3.9 \%)$ \\
Antepartum hemorrhage & 7 & $(3.1 \%)$ \\
Decline in fetal movements & 4 & $(1.7 \%)$ \\
Preterm labor & 3 & $(1.3 \%)$ \\
Miscellaneous indications & 7 & $(3.1 \%)$ \\
\hline Total & 229 & \\
\hline
\end{tabular}

time that a fetus survived after repeated late decelerations had been observed for the first time, was 10 days. In one patient the $\mathrm{L} / \mathrm{S}$ ratio was low and time was allowed for glucocorticoids to improve the lung maturity but intrauterine death occurred before the fetus could be delivered. In another patient cesarean section was planned but intrauterine death occurred before the operation could be done. The third intrauterine death was due to abruptio placentae and the fourth was an unexpected macerated twin where a cesarean section was done for a positive stress test in the other twin. Only one of the stillbirths had a congenital abnormality namely an umbilical hernia and abnormal hands and feet. In total there were 10 babies $(4.4 \%)$ with congenital abnormalities of which one was stillborn, 4 died neonatally bringing the perinatal mortality to $50 \%$ (table II). Four babies had chromosomal abnormalities $(1.7 \%)$ : two with trisomy-21, one with trisomy-18 and one was a true hermaphrodite. Ages of the mothers who had babies with trisomy-18 were 49 and 46 years.

\section{Discussion}

The incidence of congenital abnormalities in this study was $4.4 \%$. When one looks at the general incidence of congenital abnormalities in a larger population it varies between 2 and $3 \%$ [4]. According to another source the incidence of gross deformities is $1.5 \%$ while the incidence of both gross and minor abnormalities after 1 year is $4-5 \%$ [11]. When only the genetic abnormalities found in this study are considered, the incidence of $1.7 \%$ is much higher than the reported $0.62 \%$ in a large pooled study of 56952 newborns [3]. It is even higher than the incidence of $1.6 \%$ reported in patients where antenatal amniocentesis had been done for several risk factors [10].

It is clear that the incidence of congenital abnormalities is higher in patients with positive contraction stress tests. A wide range of congenital abnormalities was found of which almost half was genetic. The most frequent abnormal- 


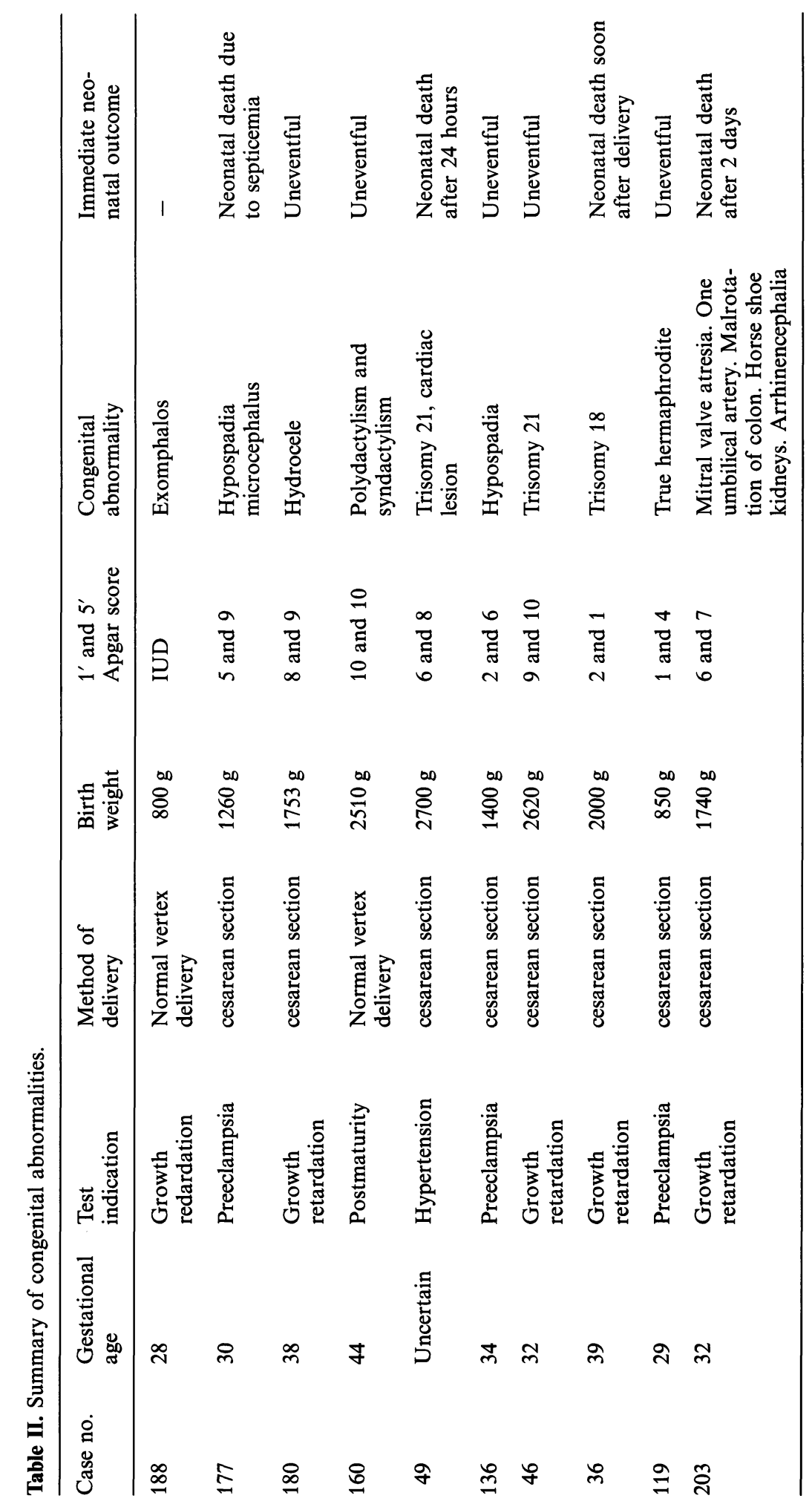


ity was trisomy-21. Although it may be inaccurate to express small numbers as a percentage, the incidence of nearly $1 \%$ found in this study is not higher than one would expect among patients where the mean maternal age was 32 years and when $39 \%$ of patients were 35 . The risk for a 37-year old patient of having a trisomy-21 is 1 in 250 [2]. Maternal ages in these two patients were 46 and 49 years. As this is much higher than that of the normal obstetric population, it is possible that these patients were selected by their age, a factor which could be associated with hypertension and growth retardation.

The perinatal mortality rate of newborns with congenital abnormalities in this study was $50 \%$, almost the same as that of the study reported by GARITE et al. [1]. In this study, all babies who died neonatally were delivered by cesarean section. As ist is undesirable to deliver a fetus with a very poor neonatal prognosis by cesarean section, one should try to exclude congenital abnormalities by ultrasound prior to delivery by cesarean section. In this study the microcephalus could perhaps have been diagnosed by ultrasound examination as a discrepancy between the femur length and bipariëtal dia- meter could have been notices. Patients with trisomy-18 demonstrating a prominent occiput and abnormal features of the hand and feet could possibly also be detected antenatally by ultrasound [6].

No specific fetal heart rate pattern occurs in patients with congenital abnormalities of the fetus. The anencephalic fetus most frequently demonstrates a silent pattern [8] and no consistent heart rate pattern occurs in the hydrocephalic fetus [5]. A fetus with Potter syndrome may demonstrate repeated variable decelerations [7] but this may be due to the severe oligohydramnios which facilitates cord compression and not due to the abnormality as such.

It seems clear that patients with congenital fetal abnormalities may present with fetal distress and that the incidence of trisomy-21 in patients with positive contraction stress tests is higher than would have normally been expected. Some of the congenital abnormalities could be detected by amniocenteses and chromosomal analyses in at risk patients. The occasional case of microcephalus or trisomy-18 may be picked up by an ultrasound examination before delivery.

\section{Summary}

Over a period of 10 years, 60197 stress and nonstress tests were done in 25313 patients. There were $229(0.9 \%)$ positive tests. In $47.2 \%$ of patients who had positive tests, preeclampsia and hypertension were the indications for the test, followed by suspected intrauterine growth retardation $(26.6 \%)$ (table I). The cesarean section incidence was $71 \%$. The mean age of the patients was 32 years. Nine per cent of patients were 45 years or older, $7 \%$ between 40 and 44 years, $23 \%$ between 35 and 39 years, $30 \%$ between 30 and 34 years, $20 \%$ between 25 and 29 years, $7 \%$ between 20 and 24 years and $4 \%$ younger than 20 years. There were 13 intrauterine deaths of which 9 fetuses were regarded as too small to be delivered. Of the remaining 4 patients, intrauterine death occurred in 3 patients before cesarean section could be done and in the fourth a macerated twin was unexpectantly found when a cesarean section was done for fetal distress. Routine autopsies were not done on intrauterine deaths. The only external abnormality that could be found was an umbilical hernia. Apart from this abnor-

mality there were 9 liveborn babies with congenital abnormalities. Four of these babies died neonatally, bringing the perinatal death rate up to $50 \%$. Four babies $(1.7 \%)$ had chromosomal abnormalities. These were trisomy-21 in two patients, a trisomy-18 and a true hermaphrodite. Ages of the patients with the trisomy-21 were 46 and 49 years. Other abnormalities were exomphalos, microcephalus with hypospadia, hydrocele, polysyndactyly and hypospadia. One newborn had several congenital abnormalities including mitral valve atresia, malrotation of the colon, absence of one umbilical artery, a horse-shoe kidney and arrhenin-encephaly. Although the incidence of chromosomal abnormalities was much higher than the general incidence in an obstetric population, it is probably due to the high maternal age in the study ( $38 \%$ of patients were 35 years or older). They were probably selected because of their hypertension. As most of the babies who died neonatally were delivered by cesarean section one would have liked to make the diagnosis of the lethal congenital abnormality 
antenatally. However, antenatal diagnosis probably was only possible in the patients with the microcephaly and with the trisomy-18. Proper antenatal screening for tris- omy-21 in the older patient should eliminate the problem of trisomy-21.

Keywords: Congenital anomalies, fetal heart rate, nonstress tests, stress tests.

\section{Zusammenfassung}

\section{Die Häufigkeit kongenitaler Mißbildungen bei Patientin- nen mit pathologischem CTG}

In einem Zeitraum von 10 Jahren wurden bei 25313 Schwangeren 60197 kardiotokographische Untersuchungen (CTG) mit und ohne Belastung durchgeführt. In 229 Fällen $(0,9 \%)$ ergab sich ein pathologisches CTG. Hiervon war bei $47,2 \%$ die Durchführung des CTG wegen einer bestehenden Präeklampsie oder Hypertonie indiziert, während es sich bei weiteren $26,6 \%$ (Tabelle I) um einen Verdacht auf intrauterine Mangelentwicklung handelte. Die Kaiserschnittrate betrug 71\%. Das Durchschnittsalter der Schwangeren lag bei 32 Jahren. Bei $9 \%$ der Patientinnen lag die Altersgrenze jenseits von 45 Jahren; in 7\% lag das Alter zwischen 40 und 44 Jahren, in $23 \%$ zwischen 35 und $39 \mathrm{Jahren}$, in $30 \%$ zwischen 30 und $34 \mathrm{Jahren}$, in $20 \%$ zwischen 25 und 29 Jahren, in $7 \%$ zwischen 20 und 24 Jahren, während $4 \%$ jünger als 20 Jahre waren. Bei 13 Frauen bestand ein intrauteriner Fruchttod, wobei es sich in 9 Fällen um Feten handelte, die aufgrund ihrer Unreife für nicht lebensfähig befunden wurden. Bei den verbleibenden 4 Schwangeren kam es in 3 Fällen zum intrauterinen Fruchttod, bevor eine Sectio durchgeführt werden konnte. Bei dem vierten Fall wurde anläßlich eines Kaiserschnittes wegen drohender intrauteriner Asphyxie unerwartet ein mazerierter Zwilling entdeckt. Eine Routineautopsie der Totgeburten wurde nicht durchgeführt. Als einzige äußerlich erkennbare Abweichung konnte nur eine umbilikale Hernie festgestellt werden. Abgesehen von diesem Befund bestanden kongenitale Fehlbildungen bei weiteren 9 lebenden Neugeborenen. Hiervon starben 4 Kinder während der Neonatalperiode, womit sich eine perinatale Mortalität von $50 \%$ ergab. Bei 4 Neugeborenen $(1,7 \%)$ bestanden chromosomale Aberrationen: 2 Mütter hatten je ein Kind mit einer Trisomie 21, ein weiteres Kind hatte eine Trisomie 18, und im vierten Fall handelte es sich um einen echten Hermaphroditen. Das Alter der Mütter mit den an Trisomie 21 leidenden Kindern lag bei 46 und 49 Jahren. Ferner wurden folgende Mißbildungen entdeckt: Exomphalos, Mikrozephalie mit gleichzeitig bestehender Hypospadie, Hydrozele, Polysyndaktylie und Hypospadie. Bei einem der Neugeborenen bestanden verschiedene kongenitale Mißbildungen, gekennzeichnet durch Mitralklappenatresie, Malrotation des Kolons, Fehlen einer Umbilikalarterie, Hufeisenniere und Arhinenzephalie. Obwohl die Häufigkeit chromosomaler Aberrationen weitaus über dem Durchschnitt lag, muß als Möglichkeit hierfür das relativ hohe mütterliche Alter in Rechnung genommen werden $(38 \%$ der Untersuchten war 35 Jahre oder älter). Es handelte sich dementsprechend um eine selektierte Gruppe, wahrscheinlich aufgrund der bestehenden Hypertonie. Da die meisten während der Perinatalperiode verstorbenen Kinder mittels Kaiserschnitt entbunden wurden, wäre es von großem Vorteil, den Befund einer letalen angeborenen Mißbildung bereits ante partum zu erheben. Eine derartige vorgeburtliche Diagnose wäre wahrscheinlich nur möglich gewesen in den Fällen mit fetaler Mikrozephalie und Trisomie 18. Die regelmäßige Durchführung genetischer Untersuchungen für Trisomie 21 bei allen älteren Schwangeren könnte das Problem dieser Mißbildung eliminieren.

Schlüsselwörter: Antenatale Kardiotokographie, CTG mit Belastung, fetale Herzfrequenz, kongenitale Mißbildungen.

\section{Résumé}

\section{Prévalence des anomalies congénitales chez les patientes} ayant un test au syntocinon positif

Sur une période de 10 ans, on a réalisé 10197 enregistrements du rythme cardiaque fœtal avec et sans tests au syntocinon chez 25313 patientes. 229 enregistrements $(0,9 \%)$ ont été positifs. L'indication de l'enregistrement du rythme cardiaque était une pré-éclampsie ou une hypertension artérielle chez $47,2 \%$ des femmes présentant un tracé positif, une suspicion de retard de croissance intra-utérin chez 26,6\% (tableau I). L'incidence de la césarienne a été de $71 \%$. L'âge moyen des patientes était de 32 ans. $9 \%$ des patientes avaient 45 ans ou plus,
$7 \%$ entre 40 et 44 ans, $23 \%$ entre 35 et 39 ans, $30 \%$ entre 30 et 34 ans, $20 \%$ entre 25 et 29 ans, $7 \%$ entre 20 et 24 ans et $4 \%$ de moins de 20 ans. Il y a eu 13 morts fœtales in utero dont 9 chez des fætus considérés comme trop petits pour être extraits. Parmi les 4 autres patientes, la mort in utero est survenue chez 3 patientes avant que la césarienne puisse être effectuée, chez la quatrième on a découvert de façon inattendue un jumeau macéré lors de la césarienne effectuée pour souffrance fotale. Il n'a pas été effectué d'autopsie de routine pour les morts fœtales in utero. Une hernie ombilicale a été la seule anomalie externe retrouvée. En dehors de cette anoma- 
lie, il y a eu 9 enfants vivants avec des anomalies congénitales. 4 de ces enfants sont morts à la période néonatale ce qui amène la mortalité périnatale à $50 \%$.

Quatre enfants $(1,7 \%)$ étaient porteurs d'anomalies chromosomiques. Il s'agissait de 2 trisomiques 21 , d'une trisomie 18 , et d'un cas d'hermaphrodisme vrai. L'âge des patientes avec un enfant trisomique 21 était de 46 ans et de 49 ans. Les autres anomalies étaient omphalocèle, microcéphalie avec hypospadias, hydrocèle, polysyndactylie et hypospodias. Un nouveau-né présentait des malformations multiples: atrésie mitrale, malrotation colique, absence d'une artère ombilicale, rein en far à cheval et arhinencéphalie. L'incidence des anomalies chromoso- miques était nettement supérieure à celle de la population obstétricale générale, cela est probablement secondaire à l'âge maternel élevé dans notre étude $(38 \%$ des patientes avaient 35 ans ou plus). La sélection s'est probablement réalisée en raison de leur hypertension. Comme bon nombre d'enfants morts en périose néonatale sont nés par césarienne, on aimerait faire le diagnostic des anomalies congénitales léthales avant la naissance. Néanmoins, le diagnostic prénatal aurait pu être possible uniquement chez les patientes avec l'enfant microcéphase et le trisomique 18 . Un diagnostic prénatal approprié pour la trisomie $21 \mathrm{chez}$ les patientes âgées devrait supprimer le problème de la trisomie 21 .

Mots-clés: Anomalies congénitales, cardiotocographie prénatale, rythme cardiaque fœtal, test au syntocinon.

\section{References}

[1] Garite TJ, EM LinZey, RK FreEMAN, W DorchESTER: Fetal heart rate patterns and fetal distress in fetuses with congenital anomalies. Obstet Gynecol 53 (1979) 716

[2] Guide to Genetic Disorders: Down Syndrome. Department of Health and Welfare, Pretoria 1981

[3] HoOK EB, JL Hamerton: The frequency of chromosome abnormalities in consecutive newborn studies. In: HoOK EB, IH PORTER (eds): Population Cytogenetics - Studies in Humans. Academic Press, London 1977

[4] LLEWELlYN-JoNES D: Fundamentals of Obstetrics and Gynaecology. Vol 1, 3rd ed. Faber and Faber, London 1982

[5] MCCRANN DJ, BS SCHIFRIN: Heart rate patterns of the hydrocephalic fetus. Am J Obstet Gynecol 117 (1973) 69

[6] MULLER L: The prenatal ultrasonographic features of the Pena-Shokeir. I syndrome and the trisomy18 syndrome. Am J Med Genet (in press)
[7] Peleg D, D Dicker, N Samuel, D Feldberg, JA Goldman: FHR patterns in Potter's syndrome. J Perinat Med 11 (1983) 179

[8] Peleg D, JA Goldman: Fetal heart patterns - a study of the anencephalic fetus. Obstet Gynecol 53 (1979) 530

[9] Phelan JP: The nonstress test: a review of 3000 tests. Am J Obstet Gynecol 139 (1981) 7

[10] OP'T HoF J: Genetic Services Report 1983/84. Department of Health and Welfare, Pretoria 1984

[11] Shore SCL, MP KeEt, VC HARrison: The Newborn Baby. Juta and Co Ltd, Cape Town 1978

[12] Tushuizen PBTh, JEGM Stoot, JMH Ubachs: Clinical experience in nonstressed antepartum cardiotocography. Am J Obstet Gynecol 128 (1977) 507

Received April 15, 1986. Accepted September 1986.

Hein J. Odendaal, M. D.

Departement of Obstetrics and Gynecology P. O. Box 63

7505 Tygerberg

South Africa 